\title{
Evaluation of the Potential of Ozone as a Power Plant Biocide
}

\author{
J. S. Mattice \\ J. R. Trabalka \\ S. M. Adams \\ R. A. Faust \\ R. L. Jolley
}




\section{DISCLAIMER}

This report was prepared as an account of work sponsored by an agency of the United States Government. Neither the United States Government nor any agency Thereof, nor any of their employees, makes any warranty, express or implied, or assumes any legal liability or responsibility for the accuracy, completeness, or usefulness of any information, apparatus, product, or process disclosed, or represents that its use would not infringe privately owned rights. Reference herein to any specific commercial product, process, or service by trade name, trademark, manufacturer, or otherwise does not necessarily constitute or imply its endorsement, recommendation, or favoring by the United States Government or any agency thereof. The views and opinions of authors expressed herein do not necessarily state or reflect those of the United States Government or any agency thereof. 


\section{DISCLAIMER}

Portions of this document may be illegible in electronic image products. Images are produced from the best available original document. 
Printed in the United States of America. Available from National Tcchnical Information Servir:e

U.S. Department of Commerce

5285 Port Royal Road, Springfield, Virginia 22161

Price: Printed Copy $\$ 5.25$; Microfiche $\$ 3.00$

This report was prepared as an account of work sponsored by an agency of the United States Government. Neither the United States Government nor any agency thereof, nor any of their employees, contractors, subcontractors, or their employees, makes any warranty, express or implied, nor assumes any legal liability or responsibility for any third party's use or the results of such use of any information, apparatus, product or process disclosed in this report, nor represents that its use by such third party would not-infringe privately owned rights. 
Contract No. W-7405-eng-26

eVAluation of the POTENTIAL OF OZONE AS A POWER PLANT BIOCIDE

J. S. Mattice, J, R. Trabalka, S. M. Adams,

R. A. Faust, 1 and R. L. Jolley?

ENVIRONMENTAL SCIENCES DIVISION

Publication No. 1219

1 Information Division.

${ }^{2}$ Chemical Technology Division.

NOTICE

This report was prepated as an account of work

sponsored by the United States Govemment. Neither the

Energy Ste United States Department of

endreir

any wars, subchlractors, or their employees. makes

limplied, or assumes any legal

the accuracy, completeness

or usefulness of any information, apparatus, product or

process disclosed, or represents that its use would not infringe privately owned rights.

Date Published - September 1978

OAK RIDGE NATIONAL LABORATORY

Oak Ridge, Tennessee 37830

operated by

UNION CARBIDE CORPORATION

for the

DEPARTMENT OF ENERGY 
THIS PAGE

WAS INTENTIONALLY

LEFT BLANK 
ORNL/TM-6459

\title{
ACKNOWLEDGMENTS
}

\begin{abstract}
We would like to thank B. G. Blaylock, Environmental Sciences Division, and M. H. Lietzke, Chemistry Division, Oak Ridge National Laboratory for many helpful comments on the manuscript.
\end{abstract}


THIS PAGE

WAS INTENTIONALLY

LEFT BLANK 
MATTICE, J. S., J. R. TRABALKA, S. M. ADAMS, R. A. FAUST, and R. L. JOLLEY. 1978. Evaluation of the potential of ozone as a power plant biocide. ORNL/TM-6459. Oak Ridge National Laboratory, Oak Ridge, Tennessee. 72 pp.

A review of the literature on the chemistry and biological effects of ozone was conducted to evaluate the potential of ozone to function as a power plant biocide. Evaluation of this potential is dependent upon determining the ability of ozone to maintain the integrity of both the condenser cooling system and the associated ecosystem. The well-known bactericidal capacity of ozone and the limited blofouling control studies conducted thus far suggest that ozone can control both slime and macroinvertebrate fouling at power plants. However, full-scale demonstrations of the minimum levels of ozone required and of solution of the practical aspects of application have not been performed.

Information relating to environmental effects of ozonation is also insufficient for any but tentative conclusions. Identification of ozonation products in potential power plant effluent waters has not been attempted. By analogy with known products in ozonated waste waters and from theoretical considerations, the most common compounds expected in power plant effluents are residual ozone, aldehydes, ketones, and carboxylic acid molecules. Decomposition of residual ozone is apparently slow enough to allow transport into the external environment. Residual ozone is toxic to some aquatic organisms at concentrations as low as several hundredths of a part per million for 
short exposure durations. Most aldehydes, ketones, and carboxylic acids are moderately low in toxicity and probably would not represent an environmental problem at the concentrations likely to be released. However, studies in aqueous media have indicated the possibility of formation of ozonated organics of potential environmental or public health concern. These reaction products include epoxides, peroxides, and stable hydroperoxides. Other studies have indicated the presence of hydroxylated and oxidized PAHs, amine oxides, and nitrosoamines. Potential for an even broader variety of products is indlcated by results of laboratory studies and the known complexity of compounds found in natural waters. Some compounds of the above generic types have been found to be highly toxic, mutagenic, or carcinogenic. Existing data thus point to a potential for environmental effects of ozonated effluents, but the extent to which that potential will be realized under conditions of ozone application at power plants is not possible to estimate with assurance. The supposition that this potential is relatively low, however, implies that this is a propitious time for support of a limited research program designed to initiate evaluation of ozone as a power plant bivcide. 


\section{TABLE OF CONTENTS}

Page

ABSTRACT . . . . . . . . . . . . . . . . . v v

LIST OF TABLES . . . . . . . . . . . . . . . . . . . ix

LIST OF FIGURES . . . . . . . . . . . . . . . . . xi

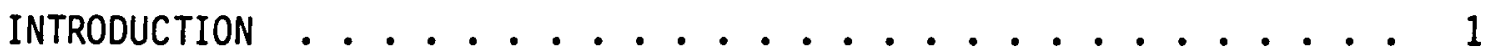

OZONE LITERATURE SEARCH . . . . . . . . . . . . . . . 2

CHEMICAL ASPECTS OF OZONATION OF POWER PLANT COOLING WATER. • . 6

Introduction .................. 6

Primary $\mathrm{Cl}$ asses of Ozone Reactions .......... 8

Ozone Reactions with Organics . . . . . . . . . 14

Ozonation of Organics in Natural Waters . . . . . . . 24

Summary . . . . . . . . . . . . . . . 25

BIOLOGICAL ASPECTS OF OZONATION OF POWER PLANT COOLING WATERS . . 25

Introduction . . . . . . . . . . . . . 25

Applications of Ozone .................. 27

Effects on Aquatic Organisms ............. 33

Ozone and Chlorine Comparisons ........... 37

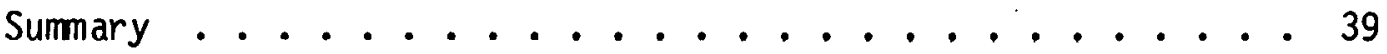

CONCLUSIONS AND RECOMMENDATIONS . . . . . . . . . . . . 40

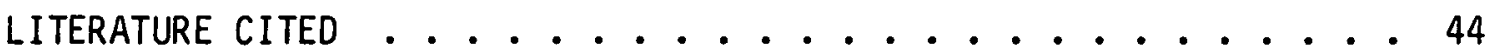




\section{THIS PAGE}

WAS INTENTIONALLY

LEFT BLANK 


\section{LIST OF TABLES}

$\underline{\text { Table }}$

Page

1 Ozone decomposition rates under several experimental

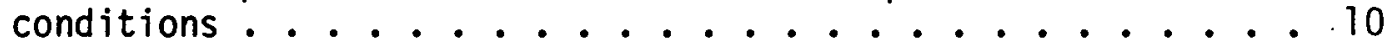




\section{THIS PAGE}

WAS INTENTIONALLY

LEFT BLANK 


\section{LIST OF FIGURES}

Figure

Page

1 Categories of information required for evaluation of ozone as a power plant biocide ..........

2 Reactions of substrates (S) with $0^{3}$ and the $0^{3}$ decomposition reaction compete for $0^{3}$ consumption (from Hoigne and Bader 1976) ........... 12

3 Revised Criegee ozonolysis mechanism (adapted from Carlson and Caple 1977).............. 15

4 Intermediate formed following ozonation of phenol . . . 19

5 Mutagenic compound formed following ozonation of ethanol..................... 23 
ORNL/TM-6459

\section{INTRODUCTION}

Substantial interest has recently surfaced concerning the potential use of ozone (and other alternatives to chlorine) as a biofouling control agent at electric generating stations. About $90 \%$ of the power plants in the United States currently use chlorine for control of fouling (McLean 1973, Brungs 1976). This preponderance of use has resulted from the early discovery of its effective biocidal capacity, simplicity of application, and economy. However, increasing awareness of the potential health and environmental impacts of both residual chlorine (Mattice and Zittel 1976, Mattice 1977) and chlorinated organics (Jolley 1973, Alavanja et al. 1978) have stimulated reexamination of alternatives to avoid these problems. Ozone has received much of the emphas is of this search.

This emphasis on ozone has resulted from three characteristics. First, it is an excellent bactericide, rendering it potentially effective in controlling slime communities, which are the major cause of decreased heat exchange across condensers. Second, residual ozone is subject to relatively rapid degradation in natural waters, decreasing potential interactions with biota in the receiving water body. Finally, the major breakdown product is oxygen, which should improve water quality at levels not resulting in supersaturation. These characteristics indicate a good potential for use of ozone as a biocide at power plants.

The prognosis for biofouling control using ozone is not, however, entirely optimistic. Ozone is (1) costly and difficult to use, and (2) 
potentially capable of reacting with organic materials in natural waters to produce ozonated organics of health and environmental consequence (Cotruvo 1976). These aspects of ozone use suggest that ozone may not be a panacea for the concerns voiced regarding chlorine.

Evaluation of ozone as a power plant biocide is dependent upon capacity to satisfy two criteria: maintenance of condenser function and avoidance of environmental impact. Resolution of the potential conflict between these criteria requires a broad base of information (Fig. 1). Determination of the minimum dosage necessary to maintain condenser function is a key component of the evaluation. It provides a sound basis for identification and quantification of effluent reaction products and sets levels for realistic investigations of effluent toxicity. Once data are available in each of these areas (Fig. 1), comparison of ozone and other biocides, particularly chlorine, is possible. Without these data, comparisons can only be tentative.

The following sections review the available literature concerning ozone to determine whether there are sufficient data on the various aspects discussed above to select ozone as a viable alternative to chlorine in preventing fouling at power plants. The sections report (1) the depth and breadth of the literature search, (2) the chemistry, and (3) the biology of ozone as they apply to this goal.

\section{OZONE LITERATURE SEARCH}

The search of the literature for documents concerning ozone represents an expansion of previous efforts. Since 1971 the ORNL Ecological 
ORNL-DWG $78-12664$

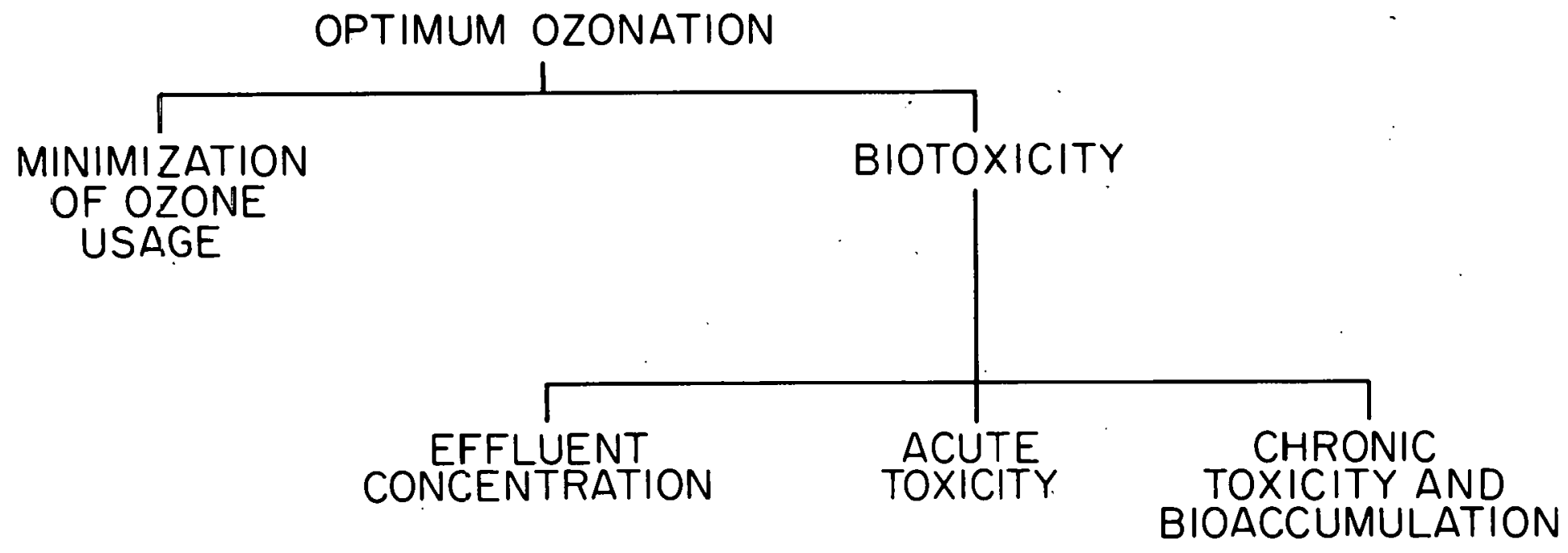

Fig. 1. Categories of information required for evaluation of ozone as a power plant biocide. 
Sciences Information Center (ESIC) has been compiling annotated data bases to aid in the assessment of ecological effects of cooling systems of electric generating plants. Existing data bases related to power plant operation include thermal effects, impingement, entrainment, and chlorine. Using seed money allocated in early 1977 by the Exploratory Studies Program, ORNL, Oak Ridge, Tennessee, this effort was expanded to include literature concerning the chemistry of ozone and its degradation products as well as the effects of these compounds on aquat1c biota. This literature was systematically collected and abstracted for inclusion into a computerized data base.

Potentially appropriate titles were identified using several methods. The large-scale commercial data bases of the ORSDI (Oak Ridge Selective Dissemination of Information) were searched for pertinent information. The data bases consulted were: Biological Abstracts (BA); Bio-Research Index (BRI); Chemical Abstracts, Even Issues (CAE) and Odd Issues (CAO); National Agricultural Library (CAIN); ChemicalBiological Activities (CBAC); and Government Reports Announcements (GRA). Both current and retrospective searches were carried out. Following review of the abstracts obtained from these data bases, papers which appeared to be within the scope of the project were obtained. The documents, comprising environmental journals, conference procéedings, and books, were acquired by reprint cards, by interlibrary loans, and by personal contacts. Additional documents were then derived from the bibliographies of these studies and from personal contacts with certain of the authors identified. All of the papers are available in the Ecological Sciences Information Center files. 
Somewhat less than two hundred papers were considered to contain information pertinent to project goals. More than 1000 citations from the open literature were scanned. A total of 323 documents were acquired. After discussions with project staff members (in ecology and chemistry), 170 of these were selected for input into a computer data base. An annotated bibliography of abstracts of these papers will soon be available. The documents which were acquired but were found not to be in scope at the present time are being held for possible later expansion of the data base.

The literature on the chemistry of ozone deals primarily with the decomposition of ozone in aqueous solution, general ozonation. reactions, reactions of ozone and selected organics, and the identification of decomposition products formed by the interactions of ozone with organic compounds. The question of epoxide and ozonide formation is addressed in some papers.

Documents related to biological effects deal predominantly with the bactericidal and virucidal properties of ozone. Most of the toxicity studies concern the lower aquatic organisms although some information is given on higher order animals. Papers on freshwater systems predominate although limited information is available on marine systems. Examples of the types of papers selected are: disinfection of drinking water, disinfection of sewage effluents, and biofouling control: comparative effectiveness of chlorinc and ozone as biocides; use of ozone in fish hatcheries, shellfish culture, and seaquaria and aquaria; effects of ozone on the cellular level; bioassay studies; 
mutagenic screening of some decomposition products; and acute and chronic effects of residual ozone on fish and invertebrates.

CHEMICAL ASPECTS OF OZONATION OF POWER PLANT COOLING WATERS

\section{Introduction}

Relatively little information is available concerning the chemistry of ozone following its use in prevention of biofouling of condenser surfaces in electric power plant cooling systems. A thoruugh sedrch has been made for studies and information concerning the chemistry of ozone and possible effects on the constituents in natural waters, which may be used for condenser cooling. Although much information is available concerning the use of ozone in nonaqueous chemical reactions, only scant information was found concerning ozonation products in aqueous systems and, in particular, those systems with low concentrations of organic constituents and low concentrations of ozone application. Both conditions would be found at power plants. Investigations into this complex and difficult area have only recently been initiated, following development of instrumentation with sufficient capability and sensitivity to detect and identify organic constituents at part-per-billion concentrations (Sievers et al. 1977).

The chemistry and ozonation reactions of ozone that are applicable to understanding possible effects on the constituents in cooling water are reviewed in this paper. The physical and chemical properties of ozone per se (e.g., thermodynamic properties) will not be reviewed. 
Experimental evidence indicates that product formation following ozonation will differ in marine (or estuarine) and fresh waters. Ozone is a very reactive species with an oxidation potential of $2.07 \mathrm{~V}$, second only to fluorine. Consequently, ozone will oxidize chloride and bromide present in cooling waters according to the following equations:

$$
\mathrm{O}_{3}+2 \mathrm{H}^{+}+2 \mathrm{Cl}^{-} \gtrless \mathrm{O}_{2}+\mathrm{Cl}_{2}+\mathrm{H}_{2} \mathrm{O}
$$

and

$$
\mathrm{O}_{3}+2 \mathrm{H}^{+}+2 \mathrm{Br} \gtrless \mathrm{O}_{2}+\mathrm{Br}_{2}+\mathrm{H}_{2} \mathrm{O}
$$

These reactions occur rapidly in acid solutions, but only the bromide reaction may occur at a rate sufficiently rapid to form halogenated organics and then only at the higher concentrations of bromide that occur in estuarine and marine waters (Taube 1942). Free bromine or chlorine would hydrolyze rapidly to hypobromous to hypochlorous acids in aqueous solution. These will react rapidly with organic material present in the natural water to produce haloforms (Rook 1974). Apparently, ozonation of drinking water supplies does not form trihalomethanes (Symons 1976), thus giving presumptive evidence that the chloride in fresh waters is either oxidized slowly to chlorine or that any chlorine formed is rapidly converted to chloramines (Symons 1976). It is believed that the kinetics of the chloride oxidation are not favorable at neutral pH values and at low ozone and chloride concentrations. However, ozonation of estuarine and sea water does result in the production of bromoform (Carpenter and Smith 1978, Helz et al. 1978, Mangum and MCLlhenny 1975, Pitchet and Hurtbise 1976, 
Blogoslawski and Stewart 1976, Blogoslawski et al. 1976). Thus, ozonation of estuarine and marine cooling waters probably also creates other bromo-compounds in addition to bromoform. The formation of halogenated organics during ozonation must, therefore, be considered a possibility in at least some cooling waters.

The actual proportions of the products formed are dependent upon the relative reaction rates under the prevailing conditions, but few data are available from which to draw conclusions. Uirect reactions of ozone with materials which may exist in natural waters are given below to illustrate some of the most likely possibilities.

\section{Primary Classes of Ozone Reactions}

\section{Decomposition of Ozone}

The decomposition mechanism apparently depends on environmental $\mathrm{pH}$. Alder and Hill (1950) determined that the rate of disappearance of ozone was first order with respect to ozone in both water and carbon tetrachloride. The rates in the two media are different and much faster than in the gas phase; essentially a constant concentration of intermediates is present in the water solution. The decomposition rate is consistent with the following mechanisms:

$$
\begin{aligned}
& \mathrm{O}_{3}+\mathrm{H}_{2} \mathrm{O} \rightarrow{ }^{\mathrm{k}_{1}} \mathrm{HO}_{3}^{+}+\mathrm{OH}^{-}, \\
& \mathrm{HO}_{3}^{+}+\mathrm{OH}^{-} \underset{\mathrm{k}_{2}}{\mathrm{k}_{1}} \mathrm{PHO}_{2},
\end{aligned}
$$


and

$$
\mathrm{O}_{3}+\mathrm{HO}_{2}^{-} \rightarrow^{\mathrm{k}} 3 \mathrm{HO}^{-}+2 \mathrm{O}_{2},
$$

$$
\mathrm{HO}+\mathrm{HO}_{2} \cdot{ }^{\mathrm{k}_{4}} \mathrm{H}_{2} \mathrm{O}+\mathrm{O}_{2} \text {. }
$$

Alder and Hill (1950) assumed that reactions 3 and 5 are responsible for the ozone disappearance and are presumably slow and ratedetermining; reaction 4 is an equilibrium maintained as long as ozone is in the system, and reaction 6 is the rate-breaking step. The decay of ozone at $\mathrm{pH} 10$ to 13 and $25 \mathrm{C}$ with ozone at $10^{-4}$ to $10^{-5} \mathrm{M}$ concentrations was also determined by Czapski et al. (1968) to be first order:

$$
\frac{d\left[\mathrm{O}_{3}\right]}{d t}=k_{\text {obs }}\left[\mathrm{O}_{3}\right]
$$

where $k_{\text {obs }}=700 \underline{M}^{-1} \mathrm{sec}^{-1}$. Apparent ly, however, in more acidic solutions (pH values of 2 and 4 ), the reaction of ozone in aqueous solution is second order. At pH 6 the reaction rate is between first and second order, and at $\mathrm{pH} 8$ the decomposition rate becomes first order. At $\mathrm{pH}$ values greater than 6 the decomposition rate increases rapidly with $\mathrm{pH}$ (Hewes and Davison 1971, Stumm 1954).

There is some disagreement about the half-lives of residual ozone in aqueous solutions, but many of the predictions indicate a need for environmental concern. Table 1 compares estimates derived in two studies. Those calculated by Czapski et al. (1968) are generally larger than those of Sennewald (1933), but in most cases the times are long enough for transport into the environment. Thus, ozone itself appears 
Table 1. Ozone decomposition rates under several experimental conditions

\begin{tabular}{lllr}
\hline pH & Media & 1933 dataa & 1968 datab \\
\hline 6 & $\begin{array}{l}\text { phosphate } \\
\text { phosphate }\end{array}$ & $42.3 \mathrm{~min}$ & $26.7 \mathrm{hr}$ \\
7 & $12 \mathrm{~min}$ & $2.6 \mathrm{hr}$ \\
8 & phosphate & $25 \mathrm{~min}$ & $16.0 \mathrm{~min}$ \\
8 & borate & $16.0 \mathrm{~min}$ \\
\hline
\end{tabular}

aSennewald 1933.

bCzapski et ar. 1968. 
sufficiently stable to present some toxicity problems to downstream aquatic species.

Ozonation Reactions in Aqueous Media

Ozonation conditions can be selected to produce either direct oxidation of the organic substrate or hydroxyl radical oxidation of the organic substrate (Fig. 2). The pathway of primary importance in the acidic region, or when solutes are present that react extremely rapidly with the ozone, leads to highly selective oxidation reactions directly with organic compounds. In these oxidations, reactive groups in the organic compounds (e.g., amino groups) will be the principal focus of attack (Hoigne and Bader 1976). In more alkaline solutions favoring the decomposition of ozone to the hydroxyl radical, this radical becomes the principal oxidizing agent. The knowledge accumulated by radiation chemists and biologists concerning the hydroxylation reactions may be used to predict the products of oxidation by the hydroxy? radical (Hoigne and Bader 1976).

\section{Direct ozonation reactions}

These highly selective reactions have been the subject of much study, for example, the ozonation of the carbon-carbon double bond. The mechanism of ozonation and the reaction products do not vary significantly with type of solvent (solvent polarity) (Bailey 1972, 1975; Hoigne and Bader 1976; Oehlschlaeger 1978). Historically, the difference between these reaction types and the less selective types to be discussed later has not been recognized; however, in general, studies 


$$
\text { QRNL-DWG 78-12663 }
$$

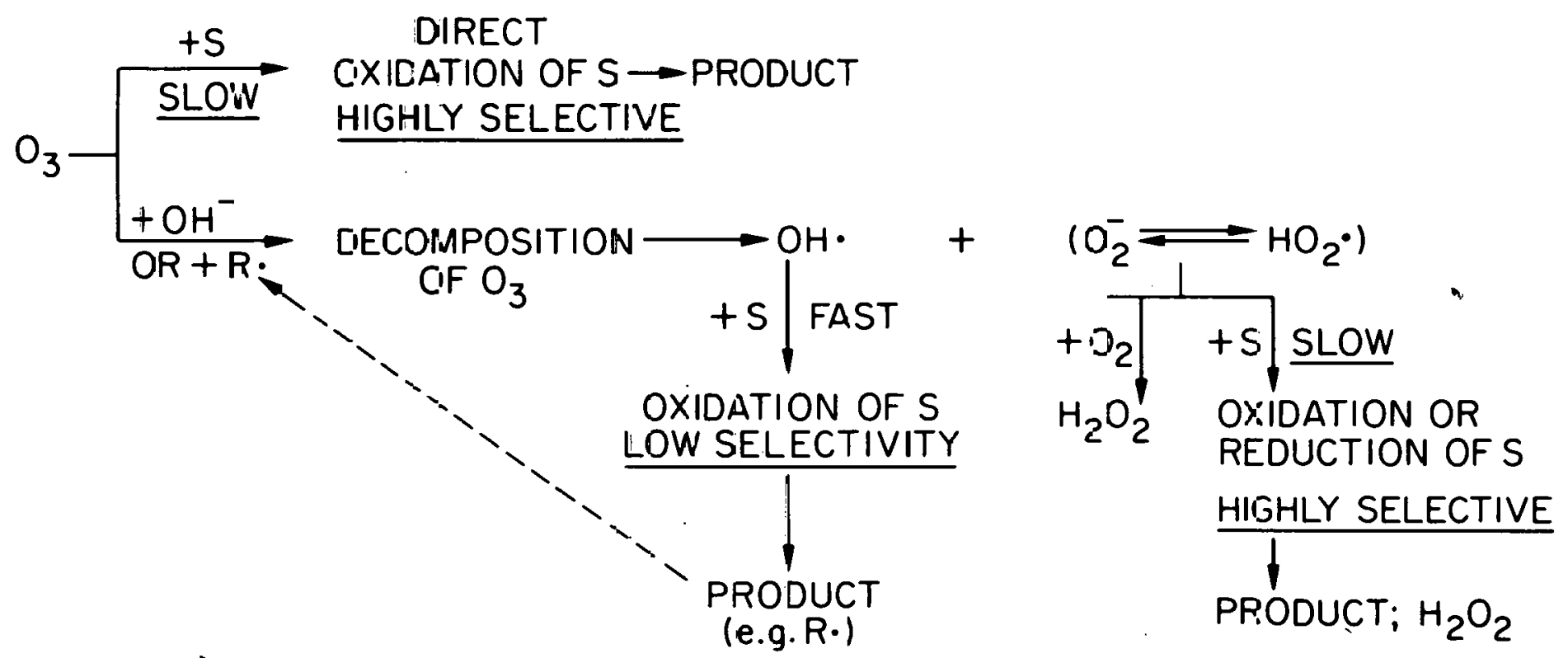

Fig. 2. Reactions of substrates (S) with $0_{3}$ and the $0_{3}$-decomposition reaction compete for $D_{3}$ consumption (from lioigne and Bader 1976). 
in nonaqueous solvents have been of the highly selective direct ozonation type. The ozonation of the olefinic double bond, and the Criegee mechanism for explaining the experimental results, is probably the best-known example of the highly selective reaction. A more complete treatment of these reactions is given below (Ozone Reactions with Organics).

\section{Hydroxyl radical oxidation}

Under reaction conditions usually prevalent in drinking-water or wastewater-treatment (and thus cooling-water treatment), reaction conditions (alkaline $\mathrm{pH}$ ) favor the decomposition of ozone into hydroxyl radicals that react less selectively with organic solutes. Experimental results confirm that $\mathrm{OH}^{*}$ radicals are the principal oxidizing intermediates formed from ozone decomposition (Hoigne and Bader 1975). Apparently, ozone decomposes in aqueous solutions by a catalyzed chain reaction involving the hydroxyl ion (Eqs. 3-6). Free radicals (e.g., $\mathrm{O}_{2}^{-}, \mathrm{HO}_{2}^{\circ}$ and $\mathrm{OH}^{\circ}$ ) could thus be formed. Because of the free radicals, the selectivity of the ozone oxidation reactions might correspond with the selectivity found in irradiated systems. At pH 10.5, good agreement was found between irradiated and ozonated systems for oxidation of selected solutes, indicating a similar mechanism operating for both agents (Hoigne and Bader 1975, Hewes and Davison 1971). The main oxidizing decomposition product of ozone in water is the $\mathrm{OH}^{*}$ radical. Thus, radiation chemistry of the $\mathrm{OH}^{\circ}$ radical can be used to predict some products of ozonation. (See: 
Anbar and Neta 1967, Dorfman and Adams 1973, Chutny and Kucera 1974a, 1974b, and Hoigne and Bader 1975, 1976).

\section{Ozone Reactions with Organics}

In this discussion, as noted earlier, ozonation reactions with organics have not been differentiated into the two major classes, i.e., direct reactions and free radical oxidations. Organic groups which can be oxidized by ozone are: olefinic carbon-carbon double bonds, acetylenic carbon-carbon triple bonds, aromatic molecules, carbocyclic molecules, heterocyclic molecules, carbon-nitrogen bonds, amines, sulfides, sulfoxides, phosphines, phosphites, arsines, selenides, alcohols, aldehydes, hydrocarbons, silicon-carbon bonds, and carbon-metal bonds (Bailey 1975). Data which exist concerning interaction of ozone with these potential reactants are sumarized below.

\section{Carbon-Carbon Double Bond}

The classical reaction of ozone with organic constituents is the ozonolysis reaction with the carbon-carbon double bond (e.g., olefinic bond) (Bailey 1958; Bailey et al. 1959, 1972). The Criegee mechanism for ozonolys is of the double bond has been elegantly detailed and explains well the reaction products (Bailey 1975) (Fig. 3). The initial attack is a 1,3-dipolar. cycloaddition to give an ozonide, a 1,2,3-trioxolane which breaks down to a carbonyl oxide zwitterion. The high energy, unstable zwitterion intermediate. stabilizes itself by polymerization or dimerization, reacts with either the aldehyde or ketone which has formed with it, or reacts with the solvent to give 


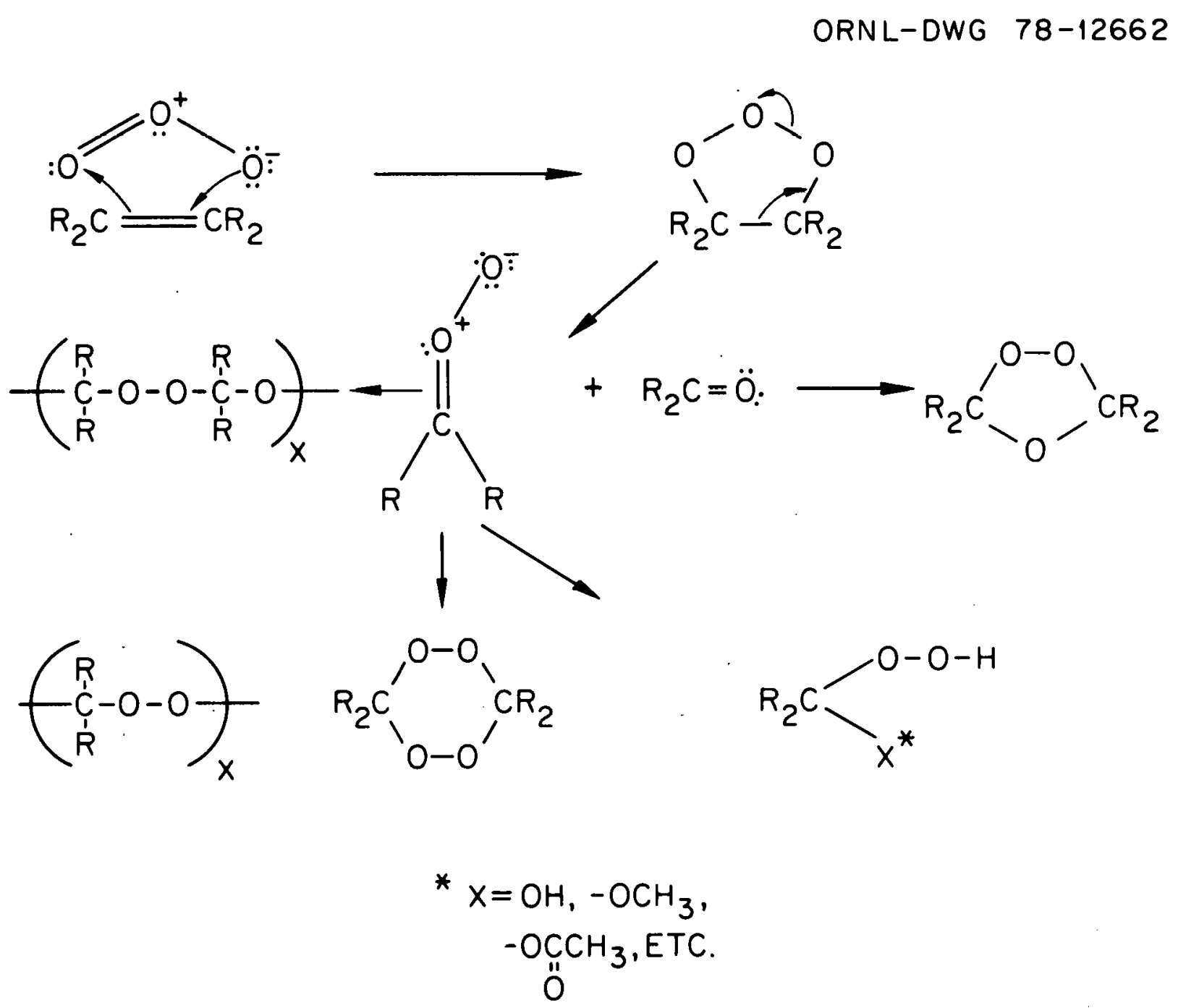

Fig. 3. Revised Criegee ozonolysis mechanism (adapted from Carlson and Caple 1977). 
peroxidic ozonolysis products. In aqueous solution the peroxidic ozonolys is products should be a hydroxy hydroperoxide. Apparently this is easily decomposed to an aldehyde (or ketone) or to a carboxylic acid (Bailey 1975). Experimental results corroborate the formation of aldehydes, ketones, and carboxylic acids (Bailey et al. 1959, 1972; Carlson and Caple 1977; Pryde et al. 1968; Criegee 1953; Fremery and Fields 1963; Fields 1965; Yocum 1978; Sturrock et al. 1963).

\section{olefins}

Ozonation of olefins can result in a wide variety of products. Most common products are esters, lactones, or anhydrides when ozonation is carried out in the presence of methyl alcohol. The formation of epoxides during ozonation is limited to olefins with strong steric hindrance at one of the carbon atoms. For example, ozonation of diphenylethylene gives a liquid ozonide and ozonation of p-Methoxystyrene yields on ly the ozonide. Unsymmetrical olefins with two strong electron-donating groups yield the epoxides instead of ozonides (Criegee 1959). Polynuclear aromatic hydrocarbons (e.g., anthracene, naphthalene, and phenanthrene) are more reactive than benzene derivatives and less reactive toward ozone than olefins. Stable hydroperoxide derivatives also can be formed during ozonation. For example, stable hyperoxides were produced following ozonation of both a cyclic olefin and a cyclic sulfone.

Ozonation of oleic acid is of particular interest because of its environmental occurrence in natural waters. Spanggord and McClurg (1978) obtained the classic ozonation products from the ozonation of 
oleic acid, namely, nonanoic acid, 9-nonanal carboxylic acid, and nonanedioic acid. They indicated the intermediate ozonides and epoxides probably did not survive the final $\mathrm{pH}$ (3.8) of their experimental reaction conditions. Similarly, Carlson and Caple (1977) ozonated oleic acid at pH 3.9 and obtained the following compounds: n-nonyl aldehyde, caprylic acid, suberic acid, n-nonyl methyl ketone, azelaldehydic acid, and azelaic acid resulting from the cleavage of the olefinic bond. All the cleavage products are predicted by the Criegee mechanism. However, in addition, oleic acid epoxide and 9,10-dihyroxystearic acid were identified. The identification of the epoxide product from an aqueous ozonation is highly significant. The noncleavage products, the oleic epoxide and the dihydroxy-substituated oleic acid, are probably not formed by the direct epoxidation of oleic acid by ozone. Instead they are likely formed by a peracid epoxidation of oleic acid; the peracids were formed by autooxidation of aldehydic products.

\section{Aromatic compounds}

Ozonation of aromatic compounds apparently involves ozonolysis at the most reactive aromatic bond and electrophilic ozone attack at individual carbon atoms. The unsubstituted benzene ring is much less reactive toward ozone than the olefinic bond. The effects of substituents on the benzene ring are similar to those of electrophilic additions in that alkyl, aryl, oxygen, etc., substituents facilitate ozonolysis, whereas nitro, carboxyl, halogen, and sulfonic acid substituents undergo slow ozonolysis reactions. The cleavage products of the benzene ring systems are glyoxals (R-CO-COH) and giyoxalic acids (R-CO-COOH) 
(Carlson and Caple 1977). The following compounds are listed in the order of decreasing reactivity toward ozone: olefins, phenanthrene, anthracene, naphthalene, and benzene (Oehschlaeger 1978). Styrene is oxidized $10^{5}$ times faster than benzene, and xylene is oxidized 25 times faster than benzene (Hoigne and Bader 1976). Yocum (1978) indicated that the ozonation of styrene produces benzaldehyde and formaldehyde intermediates and benzoic acid.

Phenol and its homologs are the only aromatic compounds studied extensively in aqueous solutions with respect to ozonation. Carlson and Caple (1977) determined the intermediates in the ozonation of phenol to be catechol, o-quinone, and muconic acid. However, Spanggord and McClurg (1978) indicated that resorcinol was also a product. This had not been previously reported. Initial electrophilic attack by the ozone and subsequent nucleophilic substitution on the ring to form an intermediate (Fig. 4) permits two modes of elimination and the formation of either catechol or resorcinol. Eisenhauer (1968) reported that ozonation of phenol proceeds through catechol and hydroquinone to the o- and p-quinones, and through muconic acids to maleic, fumaric, and oxalic acids. Gould and Weber (1976) recently determined the kinetics of phenol ozonation in addition to the kinetics of the ozonation of chemical oxygen demand (C.O.D.) and total organic carbon (T.O.C.).

\section{Miscellaneous double bonds}

Carlson and Caple (1977) determined that ozonation of alphaterpineol at either $\mathrm{pH} 3$ or 10 produced a keto-lactone. This product is consistent with the Criegee mechanism via initial alkene cleavage 


\section{ORNL-DWG 78-12661}

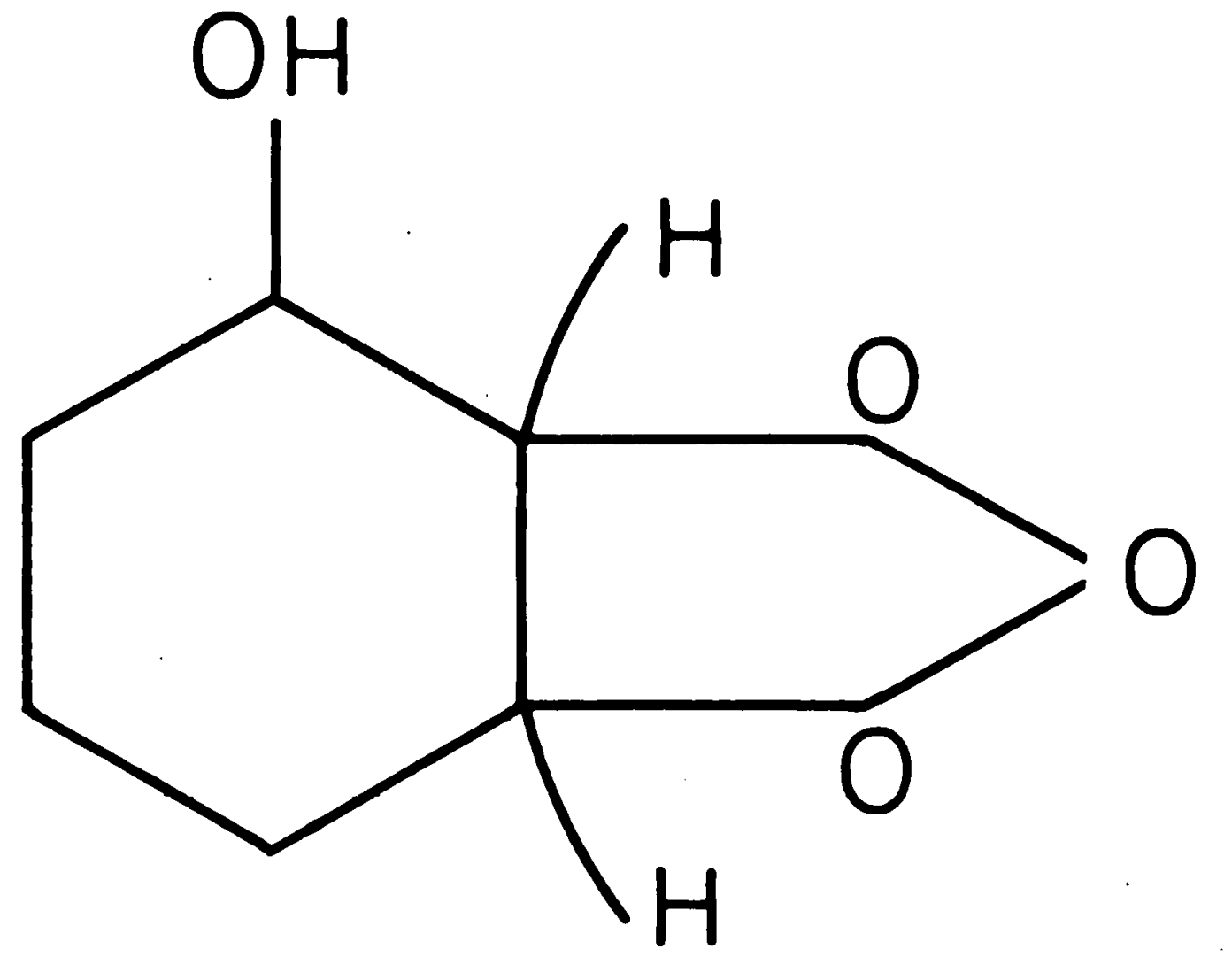

Fig. 4. Intermediate formed following ozonation of phenol. 
and the hydroxy-hydroperoxide intermediate. Other minor oxidation products were separated from the reaction media but have not been identified.

The products of ozonation of linoleic acid (with conjugated double bonds) may also be predicted by the Criegee mechanism. Some of the identified products were: n-hexanal, 2-heptanone, hexanoic acid, 9-oxopelargonic acid, azelaic acid, and 3-nonenal (Carlson and Caple 1977).

Anethole ozonates to form anisaldehyde with little ring rupture (Mosher 1959). Cinnamyl alcohol yielded normal ozonation products, glycolic aldehyde, and benzaldehyde. Benzofuran on ozonation gave salicyclaldehyde (Milas and Nolan 1959). The aromatic compounds, p-toluenesulfonic acid, naphthalene 2,7-disulfonic acid, nonylbenzenesulfonic acid, 4-chloro-o-cresol, 2-nitro-p-cresol, and p-aminobenzoic acid, were ozonated. Reaction products included methyl glyoxal, acetic acid, pyruvic acid, oxalic acid, and mesoxalic acid. In general, simple 1-carbon, 2-carbon, 3-carbon, and 4-carbon oxidation products were formed (e.g., formic, acetic, and oxalic acids) (Gilbert 1978).

\section{Carbon-Nitrogen Bonds}

Carbon-nitrogen double bonds may be as reactive toward ozone as carbon-carbon double bonds depending upon substituents. Ozone can electrophilically attack the carbon atom of the carbon-nitrogen double bond. 0ximes and hydrazones produced corresponding ketones and sometimes the $\mathrm{N}$-nitrosoamine (Erickson et al. 1969). Ozone can also act as a nucleophilic reagent in its initial attack on some carbon-nitrogen 
double bonds. Electrophilic attack appears to be the established method involved in the ozonation of the carbon-carbon double bond, the ozonation of amines, and the ozonation of sulfides. Apparently in the initial attack of ozone on Schiff bases and nitrones, it reacts as an nucleophilic agent. Ozonation of $\mathrm{N}$-benzylidine-t-butylamine yielded the corresponding amide and benzaldehyde or benzoic acid. For $\mathrm{N}$-benzylideneneaniline and $\mathrm{N}$-cyclohexylideneisobutylamine cleavage was the major reaction. Ozonation of the oximes, $\mathrm{N}$-phenylbenzaldoxime and $\mathrm{N}$-t-butylbenzaldoxime, produced benzaldehyde and the corresponding nitroso compound, which was further oxidized by ozone to the nitro compound (Riebel et al. 1960).

\section{Amines}

Spanggord and McClurg (1978) determined that two new products were produced by the ozonation of diethylamine, acetaldoxime, and a hydroxylamine or nitrosoamine. The ozonation reaction common to tertiary amines results in formation of an amine oxide,

$$
\mathrm{R}_{3} \mathrm{~N}+\mathrm{O}_{3}=\mathrm{R}_{3} \mathrm{~N}^{+}-0^{-} .
$$

Ozonation of diphenylhydrazine hydrochloride at $\mathrm{pH} 7$ produces diphenylamine, an aromatic ring-hydroxylated derivative, and a nitrogenhydroxylated derivative (Spanggord and McClurg 1978).

\section{Purines and pyrimidines (and nucleic acids)}

Products of ozonation of purines and pyrimidines have not been identified, but are probably similar to those produced by free radical attack following irradiation, and include additions of $\mathrm{OH}$ and $\mathrm{H}$ across 
the double bonds (or opening of the rings) or perhaps formation of thymine dimers. Ozone breaks the $\mathrm{C}-\mathrm{N}$ bonds of the sugars to the bases in nucleosides and nucleic acids and apparently also degrades the sugars. In addition to the chemical effects on the bases and sugars, ozone may also affect the double-stranded DNA helix, as occurs during irradiation (Scott 1975). Ozonation of caffeine produces dimethylparabanic acid as the principal product (Shapiro et al. 1978).

\section{Sulfur-Containing Compounds}

Ozone rapidly oxidizes thioglycolic acid, cysteine, and glutathione in aqueous solutions. Sulfhydryl enzymes, papain and glyceraldehyde 3-phosphate dehydrogenase, are also inactivated by ozone but may partially be reactivated by cysteine (Menzel 1971).

\section{Carbon-Hydrogen-0xygen Compounds}

Glyoxylic, oxalic, formic, and acetic acids are common endproducts of the ozonation of alcohols, phenols, malonic acld, chlorophenols, maleic acid, humic acids, and many aliphatic and aromatic compounds. It is significant that the principal component of natural waters (i.e., humic acids) are ultimately degraded to such simple products. Reaction stoichiometries were not specified (Kuo et al. 1977). Conversely, Spanggord and McClurg (1978) reported the formation of a mutagenic product from the ozonation of ethanol. The major products were an aldehyde and acetic acid. However, apparently a trimer acid peroxide (Fig. 5) is formed which is mutagenic according to the Ames test. 


\section{ORNL-DWG 78-12660}

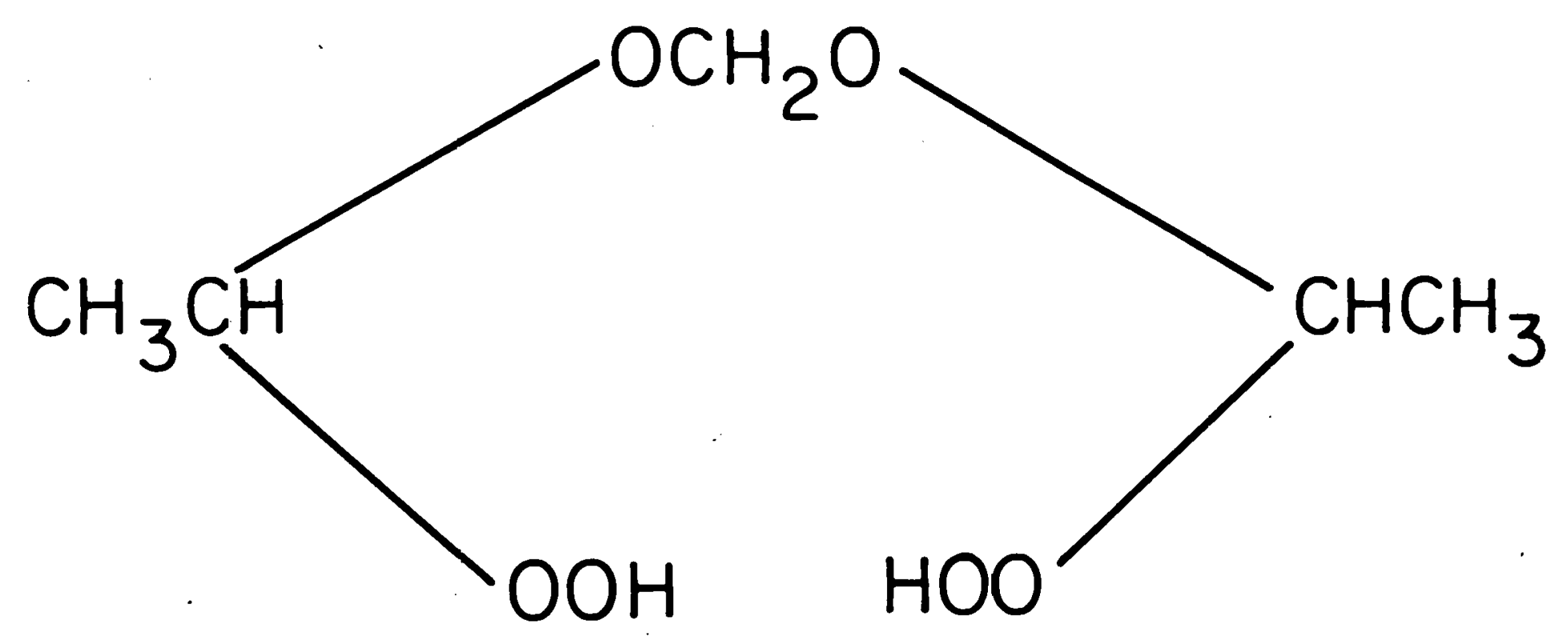

Fig. 5. Mutagenic compound formed following ozonation of ethanol. 
Ozonation of Organics in Natural Waters

The complex array of organic chemicals present in natural waters indicates that aqueous ozonation should produce myriad reaction products. Although the most prominent organic materials present in cooling waters are humic acids, almost every other known family or group of organic chemicals has also been detected in natural waters. Analysis of the U.S. Environmental Protection Agency report (Shackleford and Keith 1976) on organic constituents identified in waters of all types indicates that 55 different groups or families of organic chemicals have been identified in rivers and in effluents emptying into the rivers. Many of these, if not most, should potentially react with ozone. The concentrations and nature of ozonation products would be dictated by water quality and composition before ozonation, ozone concentrations, reaction time, and temperature.

Relatively little information concerning analyses of ozonated natural or polluted waters exist in the literature. Analysis of ozonated wastewaters has revealed that the principal volatile ozonation products are n-heptane, n-octane, n-hexanal, n-heptarlal, n-octanal, and $n$-nananal in the low and sub part-per-billion ranges (Sievers et al. 1977, 1978a, 1978b). These products are expected following ozonation of olefinic double bonds if the ozone molecule were the selertive oxidizing agent (see Carbon-Carbon Double Bonds). However, the large number of potential reactions indicates the inadequacy of this single study to delineate the limits of product formation in natural waters. 


\section{Sumary}

Although the ozonation of cooling waters has been studied relatively little, experimental results from laboratory tests indicate that a large variety of products may be anticipated following ozonation of natural waters. These products are expected to be principally aldehydic and carboxylic acid molecules. However, the list of potential products as derived from laboratory studies of ozonation of specific compounds and generic compound types is very extensive. The few studies of aqueous systems have indeed identified various aldehydes as the principal ozonation reaction products in wastewater, but at least one epoxide has been detected and identified, and a mutagenic peroxide has been isolated and identified. Stable hydroperoxides have also been formed following ozonation. Several studies have also indicated the presence of hydroxylated and oxidized PAHs, amine oxides, and nitrosoamines. These studies indicate the need for extensive attempts to determine ozonated products formed in a variety of qualities of cooling waters.

BIOLOGICAL ASPECTS OF OZONATION OF POWER PLANT COOLING WATERS

\section{Introduction}

The literature available on biological aspects of ozone includes a diversity of subjects, but there exists, however, a paucity of data concerning biological effects. Much of this literature relates to use of ozone for disinfection of wastewaters, with particular orientation toward sewage treatment. The remaining studies concern (1) other 
practical applications of ozone, (2) delineation of the effects of both residual ozone and ozonation products on mesozoan species, and (3) comparison of the relative efficiencies of ozone and chlorine as biocides with respect to both utilitarian and environmental impact considerations. All of these studies are relevant to evaluating the efficacy of ozone to function as an alternative to chlorine for biofouling control at electric generating stations.

In the following review of the ozone literature, some of the more pertinent papers and studies related to power plant usage will be summarized and evaluated. The data of concern relate to optimum use of ozone at power plants and have two foci: (1) minimization of the use of ozone, and (2) determination of the toxicity of ozone and ozonated products formed under conditions expected in the effluent, when conditions defining minimal effective levels are met. Specific objectives of this review are to determine if available information is sufficient to define (1) the effective dose-times of ozone required for biofouling control at power plants, and (2) the toxicity of residual ozone or ozonated products to aquatic organisms. Comparison of ozone and chlorine as biocides at power plants is dependent upon the capacity of the literature pertaining to ozone to satisfy these objectives.

The literature review which follows is organized into three sections to facilitate this comparison. The first two sectfons present evidence concerning the applications and toxicological effects of ozone and/or its reaction products. The third section presents data derived from studies designed specifically to compare the relative usefulness and environmental effects of ozone and chlorine. 
Applications of Ozone

The central theme of many of these papers focused on specific applications of ozone such as biofouling control, maintenance of water quality in aquaria or seaquaria, and disinfection of hatchery and waste water effluents. Although less quantitative experimental data have generally been presented in these papers, information presented is pertinent background data consistent with the objectives presented in the introduction. Separation of marine and freshwater data has not been attempted in this review because of the paucity of information related to identification of reaction products and understanding of ozone reaction mechanisms in marine systems.

Blogos lawski and Stewart (1976) reviewed the multiple applications of ozone in marine systems and suggested that ozone, under certain conditions, can produce long-lived bromo-compounds which may be harmful to aquatic life. The principal marine applications of ozone were microbial control for shellfish depuration and red tide detoxification.

\section{Biofouling Control}

The effectiveness of ozone in preventing marine fouling in seawater intake systems was examined by Mangum and McI Thenny (1975). A . continuous residual ozone concentration varying from 0.5 to $1.5 \mathrm{ppm}$ prevented the growth of barnacles, algae, and slime on test pipes. The predominant toxir. speries was heliever to be the hypobromite ion. Exposure to $1 \mathrm{ppm}$ ozone for $85 \%$ of the 168-hr test period was required to completely control fouling. Exposure for $30 \%$ of the test period did not control fouling. 
Garey (1976) investigated the effectiveness of ozone in reducing slime growth within the condensers of a marine power plant. Communities were exposed to $0.1,0.3$, and $0.6 \mathrm{ppm}$.residual ozone for time periods of 1,10 , and 100 min.. Ozone appeared to reduce growth; however, residual ozone in seawater was found to be essentially nonexistent and the effective agents were hypothesized to be hypobromous acid and hypobromite ion resulting from oxidation of bromide. Results of studies where freshwater slime communities were exposed to $0.1,0.3$, and $0.6 \mathrm{ppm}$ residual ozone for time periods of 1, 10, and $100 \mathrm{~min}$ indicated that ozone was very effective in controlling these communities (Marine Research Inc., 1977).

Studies by Toner and Brooks (1977) indicated that ozone could inhibit settling of Mytilus edulis larvae on intake tunnels but that prohibition of this settling would require constant ozonation of the intake water. This marine mollusc is primarily responsible for biofouling in the intake pipes of marine and estuarine power plants. Larvae were exposed for 5 min to 0.5 to $1.5 \mathrm{ppm}$ residual ozone, depending on larval size and water temperature. Juveniles were treated for 1 hr at 0.8 to $0.9 \mathrm{ppm}$. Smaller larvae displayed increasing susceptibility to ozone as temperatures increased, but juveniles were not affected by ozone.

After summarizing the known advantages and disadvantages (based on environmental and economic considerations) of ozone as an alternative biocide, Sengupta et al. (1974) concluded that ozone can be expected to prevent biofouling in both fresh and salt water systems, but that ozonation cannot be considered a viable technology until (1) all 
engineering problems have been solved, and (2) the expected environmental benefits exceed the additional cost of converting from present practices to ozonation. Lebourveau (1974) also expressed the concerns of the electric power industry with respect to ozone, stating that test data are needed to balance biocide effectiveness against the impact on valuable marine species. The power industry expressed hopes that a system can be found which will be selective to the fouling communities without causing harm to organisms in the receiving aquatic ecosystem. This seems unlikely.

\section{Aquaria and Oceanaria}

Application of these data to power plant situations is of questionable value because of filtration procedures which probably remove most, if not all, of the toxic materials prior to organism exposure. ozone has been utilized in several public seawater aquaria and no harmful effects to fish have been detected as long as ozone concentrations are maintained below $0.5 \mathrm{ppm}$ for less than $6 \mathrm{hr} /$ day (Sander and Rosentha 1 1974). Residual ozone can rarely be detected in these aquaria, however, because it is usually destroyed by passing the treated water through activated charcoal filters before it is returned to the fish tanks. Seaworld of Ohio ozonates 450,000 gal $\left(1.7 \times 10^{6}\right.$ liters $)$ of artificial seawater before passing it through a rapid sand filter. Only sodium chloride is used to make up the seawater, and at the ozone concentration employed, no residual ozone has been detected. Sea World of Orlando adds 1.0 to $1.5 \mathrm{lb} /$ day $(0.68 \mathrm{~kg} /$ day) of ozone (from air) to 167,000 gal $\left(0.6 \times 10^{6}\right.$ 11ters) seawater containing fish and sharks 
with no apparent harm to the organisms (Blogoslawski and Stewart 1976). Murphy (1974) indicated that even though relatively stable residual substances, currently thought to be peroxy-radicals or hypobromites, are formed when seawater is ozonized, their effects on oceanaria populations have not been observed to be detrimental. He recommended that these compounds be identified and their properties and effects on aquatic life be assessed.

\section{Hatchery Disinfection}

Results of investigations concerning the use of ozone in controlling harmful microorganisms in fish hatchery and shellfish cultures have identified ranges of residual ozone that are toxic to some selected organisms. For example, Rosenlund (1974) found that ozone residuals of 0.01 to $0.06 \mathrm{ppm}$ had to be continuously maintained in a trout hatchery effluent to kill all bacterla, but that trout exposed to these concentrations experienced $100 \%$ mortality in $4 \mathrm{hr}$. In order to reduce effects of ozonated effluents on fish it was recommended that the ozonated water be retained until the residual decomposed and gas supersaturation was eliminated.

Straub (1975) found that improved breeding and hatching yields of trout and pike in a fish hatchery could be achieved by ozonation of effluent water. Ozonated effluent was first passed through a quart.z sand filter and then aerated to remove residual ozone; no residual ozone could be detected in the effluent supplied to the fish tanks: Moffet and Shleser (1974) investigated the potential use of ozone as a disinfectant for lobster culture by exposing larvae of the American 
lobster to $0.4 \mathrm{ppm}$ ozone for $30 \mathrm{~min}$. One-third of the larvae died within six days, but no controls were run to validate these results. Reduction of harmful microflora by ozonation is believed to increase larval survival, and, according to the authors, there appears to be a potential for the use of ozone in rearing-facilities for lobster larvae.

\section{Wastewater Disinfection}

The disinfection properties of ozone have been recognized for at least a century, and treatment of water by ozonation has been adopted in many European countries, with recent interest being developed in the United States. A mass of literature exists concerning the disinfection properties of ozone and the effectiveness of ozone in water treatment. Many of the studies on this subject report dose-time relationships that kill microorganisms such as bacteria, viruses, and fungi in wastewater effluent. Some studies report the basic physical and chemical properties of the effluent, but the products of ozonation that may be the causative toxic agents have not been identified or quantified.

An excellent synthesis and summary of the existing literature related to wastewater disinfection with ozone has been given by Venosa (1975). A majority of his literature review dealt with inactivation of bacteria (E. coli) viruses or whole sewage effluents. In general, residual ozone concentrations maintained for 5 min or less at 1 to 2 ppm are adequate to ki1l most bacteria and viruses. Spores and cysts are more resistant and generally require higher doses and longer contact times (up to $4 \mathrm{hr}$ ). The conclusions states that, "there exists much controversy, contradiction, confusion, and nonfactual subjective 
judgment concerning the use of ozone for disinfection of water and wastewater." For example, he stated that it is often difficult to discern whether authors of papers he reviewed were discussing ozone residual or applied ozone when reporting data on concentrations necessary for a certain microbiocidal effects. Some of the questions that need to be answered concern the effects of ozonated effluents on fish and aquatic life, the effect of ozone on wastes, and the disinfection pattern of ozone (e.g., all-or-none effects, etc.).

Recognizing some of the unanswered questions discussed by Venosa (1975) in his review, Cronholm et al. (1976) conducted investigations to determine the feasibility of using ozone to reduce microorganisms and nonbiological pollutants in sewage effluents. Studies using 1 to 2 ppm ozone resulted in such rapid bacterial and viral inactivation that it was not possible to present survival data as a function of exposure time. The most significant result of this study, however, indicated that the nature of the water is an essential variable in determining effective ozone doses to inactivate bacteria and viruses. According to the authors, ozone in wastewater may have to be increased by a magnitude of 25 to 50 over those required to achieve equivalent virucidal cffects in drinking water. The study did not indicate the sperific compounds which inhibit ozone disinfection. In general, they found that ozone was less effective than chlorine in reducing biological and nonbiological pollutants in effluents and recommended that ozone not replace chlorine for the particular system they studied.

A comprehensive review of the literature related to ozonation of organics and identified reaction products of these organics is 
presented by Chian and Kuo (1976). The major ozonation products of various organics have been identified as formic, glyoxylic, oxalic, and acetic acids along with other aldehydes, ketones, and carboxylic acids. These compounds are known to be of low to moderate toxicity (Carlson and Caple 1977). The ozonation of these first three acids is believed to be primarily responsible for the removal of organic substances from water. Carlson and Caple (1977) ozonated various organic compounds, such as fatty acids which are common in wastewaters, and found, for example, that some oxides and epoxides were produced when oleic acid was ozonated at an $0_{3}$ flow rate of $30 \mathrm{ml} / \mathrm{min}$ for 20 to 215 min. Epoxides and peroxides are known to be highly toxic as well as mutagenic and carcinogenic under certain conditions (see section on Mutagenic Effects below).

Effects on Aquatic Organisms

Studies on the acute and chronic effects of residual ozone and its reaction products on aquatic organisms are important for indicating (1) ranges and levels of dose-time exposures effective for killing organisms or disrupting normal biotic functions, (2) relative effectiveness of ozone and other biocides for controlling organisms under various water types and, (3) possible modes of biotic-abiotic interactions occurring during biocide applications in various types of aquatic systems. These studies have generally been directed toward determination of direct effects on mortality and mutagenic effects. 


\section{Direct Effects on Mortality}

Hubbs (1930), conducting one of the first bioassays with residual ozone, reported that residual ozone concentrations as low as $0.09 \mathrm{ppm}$ were lethal to fish; crayfish died after exposure to $1.16 \mathrm{ppm}$ ozone; and "minute planktonic and bottom invertebrates" were "all more or less quickly killed" in a residual ozone concentration of $1.25 \mathrm{ppm}$. Exposure of fish generated a wide range of responses from altered locomotory and respiratory movements at the lower concentrations ( $<0.05 \mathrm{ppm})$, through loss of equilibrium and wild swimming, followed by quiescent periods terminating in death. Hubbs hypothesized that the effect of ozone was cumulative and irreversible beyond the stage of first equilibrium loss.

When unicellular algae, zooplankton, and various "worms" which are commonly found in aquarium and pond water were exposed to concentrations of residual ozone ranging from 0.3 to $0.5 \mathrm{ppm}$ for 5 to $10 \mathrm{~min}$, Bringman (1954) found that $50 \%$ of the chlorophy 11 was destroyed in the algae after a 10-min treatment; all zooplankton were killed after 5 to 6 min, and all "worms" were killed after a 10-min exposure.

The acute effects of residual ozone on four species of marine phytoplankton, crab zoea and megalops, and a small fish, the Atlantic Silversides were determined by Toner and Brooks (1974). Residual ozone concentrations of 0.08 to $0.2 \mathrm{ppm}$ killed all crab magalops and fish within $30 \mathrm{~min}$; 1 -min exposure to $0.08 \mathrm{ppm}$ residual ozone killed 30 to $40 \%$ of the crab zoea within $48 \mathrm{hr}$, and populations of marine phytoplankton decreased within 24 to $48 \mathrm{hr}$ after exposure to 0.1 to $1.0 \mathrm{ppm}$ residual ozone. The authors concluded that small residual 
concentrations of ozone adversely affect a diverse range of marine organisms and that ozone may not be a suitable biocide for antifouling because it appears to be just as toxic as chlorine to organisms exposed to power plant effluents.

Results of acute and chronic bioassays on seven species of fish, six species of invertebrates, and Daphnia magna with ozone led Arthur et al. (1975) to conclude that ozone had a potential for use in sewage treatment. No measurable toxicity to these organisms was found from either short- or long-term exposure to ozonated effluents (no residual ozone was measurable). Acute toxicity due to residual ozone was only observed when continuous levels of residual ozone were maintained in the effluents. Residual ozone concentrations of 0.2 to $0.3 \mathrm{ppm}$ killed fathead minnows after 1- to 3-hr exposures.

Ward (1976) reviewed several studies related to the effects of residual ozone on aquatic organisms. Residual ozone concentrations ranging from 0.05 to $0.23 \mathrm{ppm} \mathrm{killed} \mathrm{five} \mathrm{species} \mathrm{of} \mathrm{fish} \mathrm{within} \mathrm{a} \mathrm{time}$ range of $45 \mathrm{~min}$ (trout) to $72 \mathrm{hr}$ (goldfish). Barnacles exposed to residual ozone concentrations of 0.4 to $1.0 \mathrm{ppm}$ died within several days to a week and unknown "low" (no doses given) concentrations of ozone caused death (no times given) of seven genera of freshwater protozoa and rotifers. The conclusion of this review was that since ozone dissipates so rapidly in most natural waters, any residual ozone discharge is likely to be too little to exert adverse effects upon biotic populations of the receiving aquatic system.

The specific ozone reaction products which affect aquatic organisms have not been identified; however, some reaction products such as 
organic peroxides and hydroperoxides have been observed to have a deleterious effect on nonaquatic organisms. Peroxides have been observed to produce mutations in Drosophila (Altenburg 1954, Sobels 1956), Neurospora (Dickey et al. 1949), and in other organisms, and to induce mortality in mice (Horgan et al. 1957).

It appears, therefore, that the toxicity of ozonated organics to aquatic organisms is a justified concern that warrants investigation because: (1) ozonation of wastewater is known to produce some toxic reaction products (see sections on Wastewater Disinfection and Ozone Chemistry), and (2) some reaction products such as hydroperoxides and organic peroxides have been demonstrated to be highly toxic to various nonaquatic organisms.

\section{Mutagenic Effects}

The mutagenic effects of residual ozone on aquatic organisms are not well documented. Cotruvo et al. (1976) ozonated 28 organic compounds and investigated the mutagenic effects of the products on bacteria. Only seven of these compounds produced mutagenic activity, and then only after prolonged (up to $6 \mathrm{hr}$ ) exposure to ozone. Mutagenic activity was not related to dose, and results of many of the bioassays could not be replicated. The effects of ozone-treated seawater on the development of oyster eggs indicated that fertilization, meiosis, and cleavage were abnormal in ozone-treated water in which eggs were held at 0.18 to $0.4 \mathrm{ppm}$ for up to $2 \mathrm{hr}$ (McLean et a1. 1973). Following exposure of root meristem cells of Vicia faba to ozone, fetner (1958) 
found a high incidence of abnormal mitotic activity compared to the controls.

The specific ozone reaction products which produced the mutagenic effects in the above studies have not been identified. In nonaquatic organisms, however, organic peroxides and hydroperoxides have been shown to be capable of inducing lethal mutations in Drosophila (Altenburg 1954, Sobels 1956), Neurospora (Dickey et a1. 1949), and Escherichia coli (Davis 1959). The $\mathrm{LD}_{50}$ of linoleic acid peroxide $(0.26 \mu \mathrm{mol} / \mathrm{g})$ was comparable to the level of organic peroxide previously found in mice after receiving an $\mathrm{LD}_{50}$ dose of $\mathrm{X}$-rays $(0.22$ umol/g) (Horgan et al. 1957). Thus, organic peroxides and hydroperoxides produced in water are extremely toxic to a wide variety of organisms.

Ozone and Chlorine Comparisons

Results of acute and chronic bioassays using seven species of fish and six species of invertebrates, including Daphnia magna, led Arthur et al. (1975) to conclude that chlorinated sewage effluents were lethal to these test animals at appreciably lower concentrations than ozonated effluents. The respective 7 -day $\mathrm{TL}_{50}$ values of total residual chlorine to fish and invertebrates ranged from 0.08 to 0.26 and 0.21 to $0.81 \mathrm{ppm}$, respectively. No measurable toxicity to these organisms was found from either short- or long-term exposure to ozonated effluents. Acute toxicity in ozonated effluents was observed only when continuous levels of residual ozone were maintained in the effluents. Residual ozone concentrations of 0.2 to $0.3 \mathrm{ppm} \mathrm{killed} \mathrm{fathead} \mathrm{minnows} \mathrm{after} \mathrm{1-}$ 
to $3-\mathrm{hr}$ exposures compared to $12-\mathrm{hr}$ exposure with 0.19 to $0.34 \mathrm{ppm}$ residual chlorine.

Ward et al. (1976) conducted extensive bioassays using ozone, chlorine, and bromine chloride to determine the comparative effectiveness of these biocides as wastewater disinfectants. Acute toxicity tests were performed at various effluent concentrations on several species of fish and Daphnia magna and life-cycle toxicity studies were conducted using the fathead minnow, Pimephales promelas. Residual ozone concentrations of $0.005 \mathrm{ppm}$ or less had no effect on the survival or reproductive capacity of fathead minnows, while total residual chlorine concentrations of $0.045 \mathrm{ppm}$ or more caused growth retardation and mortality of the continuously exposed minnows. Chlorine was found to be the most toxic of the biocides tested. However, examination of the disinfection capability of ozone was often limited by inadequate dosages resulting from design limitations, mechanical failures, and operator inexperience.

Ward (1976) also presented some data on the $96-\mathrm{TL}_{50}$ concentrations of ozone, chlorine, and bromine chloride for three species of fish. Although the $96-h r-T_{50}$ values varied according to species, they generally were in the range of 0.1 to $0.2 \mathrm{ppm}$ for all three biocides. The conclusion reached was that similar concentrations of ozone and chlorine appear to produce similar short-term adverse effects on aquatic organisms.

In a study conducted at the Connecticut River Vermont Yankee Power Plant by Marine Research, Inc. (1977), ozone was shown to be a more effective biocide than chlorine in controlling freshwater slime 
communities. Freshwater slime communities were exposed to residual ozone and chlorine concentrations of $0.1,0.3$, and $0.6 \mathrm{ppm}$ for time periods of 1,10 , and $100 \mathrm{~min}$. Time of exposure was found to be more important than treatment level, and it was recommended that ozone be considered a viable alternative to chlorine in freshwater systems.

\section{Summary}

Most of the available literature pertaining to aqueous applications relates to the use of ozone for disinfection of waste water and drinking water. A very limited number of papers discussed the use of ozone for treating effluents in fish hatchery and shellfish culture systems and the potential beneficial uses of ozone for power plant biofouling control and seawater aquarium treatment. Although a significant volume of chemical papers is available, scant information on the ozonation of organic constituents in cooling waters has been found. The products of ozonation of these waters are hypothetical at this juncture, but several potential products are known to be highly toxic. For example, ozonation of oleic acid, a known constituent of wastewaters, results in formation of oleic acid oxides or epoxides. Peroxides and epoxides are known to be highly toxic as well as mutagenic and carcinogenic under certain conditions. Peroxides have been observed to produce mutations in $\underline{E}$. coli and Drosophila, and certain peroxides have been shown to be extremely toxic to mice. Toxicity of epoxides and peroxides to aquatic organisms, however, has not been determined. It appears, therefore, that the toxicity of ozonated 
organics to aquatic organisms is a justified concern that warrants investigation.

It appears that residual ozone levels of 0.01 to 1.5 are toxic to most aquatic organisms. Some of the more important nonbiological factors that determine the sensitivity of organisms to residual ozone are nature of the water (wastewater effluent, treated effluent, etc.) and salinity. Microorganisms are sensitive to lower concentrattons than macroinvertebrates and fish. Identification of the ozone residuals that are toxic to organisms has not been accomplished. Characterization of the initial, intermediate, and residual toxic species and the identification of the fate of ozone must be made before a judgment about the efficiency of ozone and accurate establishment of standards for the control of biofouling can be made.

It also appears that ozone is more effective than chlorine in controlling biofouling organisms in freshwater systems, but somewhat less effective in marine systems. The residual oxidant species of ozone and chlorine appear to be similar in seawater; however, these compounds need to be investigated, identified, and their properties and effects on aquatic life assessed.

\section{CONCLUSIONS AND RECOMMENDATIONS}

Definitive evaluation of ozone as a power plant biocide is presently impossible. Available information is insufficient to determine the degree to which ozone application at power plants can satisfy the criteria of maintenance of condenser integrity and avoidance of environmental impacts. Field studies have indicated that ozone can reduce 
fouling at marine power plants, and laboratory studies have suggested that concentrations of 0.5 to $1.5 \mathrm{ppm}$ are sufficient to control fouling. However, information is lacking on minimum required dosage and the variation of this dosage with geographical location and water quality. Potential reaction products in natural waters include a broad spectrum of compounds, but identification and quantification of ozonated materials in effluents remain virtually unstudied. Because the reaction products will undoubtedly vary with water quality, as well as ozone application level and temperature, it is not possible to assess the relevance of the toxicity studies which have been completed. The narrow range of both ozonated compounds and biotic species studied lends credence to the assumption that toxicological data are insufficient to assess the potential impacts of power plant ozonation. The questions raised previously (see Introduction) remain valid, given present knowledge of the various aspects of the potential interaction of ozone with power plant cooling waters.

A research program designed to provide information to evaluate biocidal ozonation of power plant cooling waters is both timely and justifiable. Information to allay or substantiate the concerns expressed by environmentalists and regulatory personnel regarding the health and environmental impacts of chlorination is not expected to be available prior to the early 1980s. If these potential impacts are substantial and are not ameliorable via simple measures (e.g., dechlorination), alternate biocides will be required for on-line use with as short a conversion time as possible. Information does not currently exist to define an appropriate alternate. Research now might provide 
that information in time to facilitate selection of an alternate biocide, should one be required. Justification of research specifically designed to assess ozone as an alternate is based on the studies presented in previous sections: (1) it appears to be effective in biofouling control; (2) a back-log of technical experience with application procedures already exists in the field of drinking water treatment; and (3) the major products (oxygen and aldehydic and carboxylic acid molecules) are not likely to be toxic at the concentrations expected in power plant effluents. Although a potential does exist for formation of toxic ozonated organics in cooling water effluents, this potential appears low enough to warrant further investigation.

We recommend a limited research program designed to proceed in a logical sequence of stages to evaluation of ozone as a power plant biocide. Completion of each stage should generate sufficient information to direct further studies or to discontinue research. Initial studies should focus on minimum levels required for biofouling control and acute screening bioassays of ozonated organics formed in a wide variety of natural waters. The screening bioassays should be initiated at effluent concentration leveis.

Any demonstration of toxicity would then justify steps to identify the causative agent(s) via liquid chromatographic isolation and GC/MS analysis, and to shift the scope of the project to emphasize studles of partitioning, persistence, degradation, etc. Results indicating that the causative agent(s) are moderately toxic, highly persistent, and of high bioaccumulation potential would lead to the conclusion that ozone is not a viable alternative biocide, and research could be concluded. 
If acute toxicity is not demonstrable, results from a greater diversity of bioassay regimes, including expansion of tests to include long-term chronic-exposure studies on aquatic vertebrates, must be obtained before final acceptance of ozone as an alternative biocide. A sequential procedure, such as outlined above, could prevent funding of research yielding information of little value for practical application and facilitate a reasoned evaluation of the potential of ozone for use at power plants. 


\section{LITERATURE CITED}

Alavanja, M., F. Goldstein, and M. Susser. 1978. A cast control study of gastrointestinal and urinary tract cancer mortality and drinking water chlorination. pp. 395-409. IN R. L. Jolley, H. Gorchev, and D. H. Hamilton (eds.), Conference on Water Chlorination: Environmental Impact and Health Effects. Ann Arbor Science Publishers, Ann Arbör, Mịchigan.

Alder, M. G., and G. R. Hill. 1950. The kinetics and mechanism of hydroxide ion catalyzed ozone decomposition in aqueous solution. J. Am. Chem. Soc. 72:1884-1886.

Altenburg, L. S. 1954. The production of mutations in Drosophila by Tertiary-Buty1. Proc. Natl. Acad. Sci., U.S.A. 40:1037-1040. Anbar, M., and P. Neta. 1967. A compilation of specific bimolecular rate constants for the reactions of hydrated electrons, hydrogen atoms and hydroxyl radicals with inorganic and organic compounds in aqueous solution. Int. J. Radiat. Isot. 18:493-523.

Arthur, J. W., R. W. Andrew, V. R. Mattson, D. T. 01son, G. E. G1ass, B. J. Halligan, and C. T. Walbridge. 1975. Comparative toxicity of sewage-effluent disinfection to freshwater aquatic life. EPA-600/3-75-012. EPA Environmental Research Laboratory, DuTuth, Minriesota.

Bailey, P. S. 1958. The recations of ozone with organic compounds. Chem. Rev. 58:925-1010. 
Bailey, P. S. 1972. Organic groupings reactive toward ozone:

Mechanisms in aqueous media. pp. 29-59. IN F. L. Evans (ed.), Ozone in Water and Wastewater Treatment. Ann Arbor Science Publishers, Ann Arbor, Michigan.

Bailey, P. S. 1975. Reactivity of ozone with various organic

functional groups important in water purification. pp. 101-119.

IN Proc., of First International Symposium on Ozone.

International Ozone Institute, Cleveland, Ohio.

Bailey, P. S., S. S. Bath, and J. B. Ashton. 1959. Initial attack of ozone on an unsaturated system. Adv. Chem. Ser. 21:143-148.

Bailey, P. S., J. S. Ward, R. E. Hornish, and F. E. Potts, III. 1972. Complexes and radicals produced during ozonation of olefins. Adv. Chem. Ser. 112:1.

Blogoslawski, W., L. Farre11, R. Garceau, and P. Derrig. 1976. Production of oxidants in ozonized seawater. pp. 671-681. IN R. G. Rice, P. Pichet, and M. A. Vincent (eds.), Proc., Second International Symposium on 0zone Technology. International Ozone Institute, Cleveland, Ohio.

Blogoslawski, W. J., and M. E. Stewart. 1976. Marine applications of ozone water treatment. pp. 266-276. IN E. G. Fochtman, R. G. Rice, and M. E. Browning (eds.), Disinfection with Ozone. International Ozone Institute, Cleveland, Ohio. Bringman; G. 1954. The effects of ozone on organisms in drinking water. Z. Hyg. 139:333-337. 
Brungs, W. A. 1976. Effects of wastewater and cooling water chlorination on aquatic life. EPA-600/3-76-098. U.S. Environmental Protection Agency, Washington, D.C.

Carlson, R. M., and R. Caple. 1977. Chemical/biological implications of using chlorine and ozone for disinfection. EPA-600/3-77-066. U.S. Environmental Protection Agency, Washington, D.C.

Carpenter, J. H., and C. A. Smith. 1978. Reactions in chlorinated sea water. pp. 195-20\%. IN R. L. Jolley, H. Gorchev, and D. H. Hamilton, Jr. (eds.), Water Chlorination: Environmental Impacts and Health Effects, Vol. 2. Ann Arbor Science Publishers, Ann Arbor, Michigan.

Chian, E. S. K., and P. P. K. Kuo: 1976. Fundamental study on the post treatment of Ro permeates from army wastewaters. Second Annual Surmary Report, U.S. Army Medical Research and Development Command, Washington, D.C.

Chutny, B., and J. Kucera. 1974a. Part I. Introduction, isomerization and carbon-skeleton changes, radiation synthes is in aqueous solutions. Radiat. Res. Rev. 5:1-54.

Chutny, B., and J. Kucera. 1974b. Part Iİ. Oxidation, halogenation and introduction of sulfur-containing groups into organic substanccs. Radiat. Res. Rev. 5:55-91.

Cotruvo, J. A., V. F. Simmon, and R. J. Spanggord. 1976. Investigations of mutagenic effects of products of ozonation reactions in water. Ann. N.Y. Acad. Sci. 298:124-140. 
Cotruvo, J. A. 1976. Ozone as a disinfectant of water. Presented at Workshop on Ozone/Chlorine Dioxide Oxidation Products of Organic Materials, Cincinnati; Ohio, November 16-19, 1976. U.S. Environmental Protection Agency, Cincinnati, Ohio. Criegee, Von Rudolf. 1953. Uber den Verlauf der Ozonspaltung (III. Mitteilung). Justus Liebigs Ann. Chem. 583:1-36.

Criegee, R. 1959. Products of ozonation of some olefins. Adv. Chem. Ser. $21: 133-135$.

Cronholm, L. S., J. R. McCammon, and M. Fleischman. 1976. Enteric virus survival in package plants and the upgrading of the small treatment plants using ozone. Research Report No. 98. University of Kentucky Water Resources Research Institute, Lexington, Kentucky.

Czapski, G., A. Samuni, and R. Yelin. 1968. The disappearance of ozone in alkaline solution. Israel J. Chem. 6:969-971.

Davis, I. 1959. The survival and mutability of Escherichia coli in aqueous solutions of ozone. Ph.D. dissertation, University of Pennsylvania, Philadelphia. 87 pp.

Dickey, F. H., G. H. Cleland, and C. Lotz. 1949. The role of organic peroxides in the introduction of mutations. Proc. Nat1. Acad. Sci. $35: 581-586$.

Dorfman, L. M., and G. E. Adams. 1973. Reactivity of the hydroxyl radical in aqueous solutions. National Standard Reference Data System, U.S. Department of Commerce, Washington, D.C.

Eisenhauer, H. R. 1968. The ozonation of phenolic wastes. J. Water Pollut. Control Fed. 40(11):1887-1899. 
Erickson, R. E., P. J. Andrulis, Jr., J. C. Collins, M. L. Lungle, and G. D. Mercer. 1969. Mechanism of ozonation reactions. IV. Carbon-nitrogen double bonds. J. Org. Chem. 34(10):2961-2966.

Fetner, R. H. 1958. Chromosome breakage in Vicia faba by ozone. Nature 181:504-505.

Fields, E. K. 1965. Selective oxidation processes. Adv. Chem. Ser. $51: 1-177$.

Fremery, M. I., and E. K. Fields. 1963. Emulsion ozonation of cycloolefins in aqueous alkaline hydrogen peroxide. J. Org. Chem. $28: 2537$.

Garey, J. 1976. A comparison of the effectiveness of ozone and chlorine in reducing slime growth within the condensers of an electric generating station using seawater as a coolant. pp. 277-285. IN E. G. Fochtman, R. G. Rice, and M. E. Browning (eds.), Disinfection with. Ozone. International Ozone Institute, Clevel and, Ohio.

Gilbert, E. 1978. Reactions of ozone with organic compounds in dilute aqueous solution: Identification of their oxidation products. pp. 227-242. IN R. G. Rice and J. A. Ectruro (eds.), Ozonc/Chlorine Dioxide Oxidation Producte of Organic Materials. International Ozone Institute, Cleveland, Ohio. Gould, J. P., and W. J. Weber, Jr. 1976. Oxidation of phenols by ozone. J. Water Pollut. Control Fed. 48:47-60. 
Helz, G. R., R. Sugam, and R. Y. Hsu. 1978. Chlorine degradation and halocarbon production in estuarine waters. pp. 209-222. IN R. L. Jolley, H. Gorchev and D. H. Hamilton, Jr. (eds.), Water Chlorination: Environmental Impacts and Health Effects. Ann Arbor Science Publishers, Ann Arbor, Michigan.

Hewes, C. G., and R. R. Davison. 1971. Kinetics of ozone decomposition and reaction with organics in water. J. AIChE 17(1):141-147.

Hoigne, J., and H. Bader. 1975. Ozonation of water: Role of hydroxyl radicals as oxidizing intermediates. Science 190:782-784.

Hoigne, J., and H. Bader. 1976. The role of hydroxyl radical reactions in ozonation processes in aqueous solutions. Water Res. $10: 377-386$.

Horgan, V. J., J. L. Philpot, B. W. Porta, and D. B. Roodyn. 1957. Toxicity of autoxidized squalene and linoleic acid, and of simpler peroxides, in relation to toxicity of radiation. Biochem. J. $67(4): 551-558$.

Hubbs, C. L. 1930. The high toxicity of nascent oxygen. Physiol. Z001. 3:441-460.

Jolley, R. L. 1973. Chlorination effects on organic constituents in effluents from domestic sanitary sewage treatment plants. ORNL/TM-4290. Oak Ridge National Laboratory, Oak Ridge, Tennessee. $340 \mathrm{pp}$.

Kuo, P. P. K., E. S. K. Chian, and B. J. Chang. 1977. Identification of end products resulting from ozonation and chlorination of organic compounds found in water. Environ. Sci. Technol. 11:1177. 
Lebourveau, J. W. 1974. Concerns of the electric power industry with respect to the use of ozone. pp. 115-119. IN W. J. Blogoslawski and R. G. Rice (eds.), Aquatic Applications of Ozone. International Ozone Institute, Cleveland, Ohio.

MacLean, S. A., A. C. Longwe 11, and W. J. Blogoslawski. 1973. Effects of ozone-treated seawater on the spawned, fertilized, meiotic, and cleaving eggs of the commercial American oyster. Mutat. Res. 21(5):283-285.

Mangum, D., and W. F. McIlhenny. 1975. Control of marine fouling in intake systems - A comparison of ozone and chlorine. pp. 138-153. IN W. Blogos lawski and R. G. Rice (eds.), Aquatic Applications of Ozone. International Ozone Institute, Cleveland, Ohio.

Marine Research, Inc. 1977. Alternative to chlorination, six-month progress report, 15 March 1977-15 September 1977. Marine Research, Inc., East Wareham, Massachusett.s.

Mattice, J. S. 1977. Power plant discharges: Toward more reasonable limits on chlorine. Nucl. Saf. 18(6):802-819.

Mattice, J. S., and H. E. Zittel. 1976. Site-specific evaluation of power plant chlorination: A proposal. J. Water Pullut. Control Fed. 48:2284-2308.

MCLean, R. I. 1973. Chlorine and temperature stress on estuarine invertebrates. J. Water Pollut. Control Fed. 45(5):837-841. Merizel, D. B. 1971. Oxidation of biologically active reducing substances by ozone. Arch. Environ. Health 23:149-153. 
Milas, N. A., and J. T. Nolan, Jr. 1959. Some abnormal ozonation reaction. Adv. Chem. Ser. 21:136-139.

Moffett, W. L., and R. A. Shleser. 1974. Ozone as a potential disinfectant for lobster culture. pp. 98-102. IN W. J. Blogoslawski and R. G. Rice (eds.), Aquatic Applications of Ozone. International Ozone Institute, Cleveland, Ohio.

Mosher, W. A. 1959. Structural relationships in addition of ozone to double bonds. Adv. Chem. Ser. 21:140-142.

Murphy, W. K. 1974. The use of ozone in recycled oceanarium water. pp. 87-93. IN W. J. Blogoslawski and R. G. Rice (eds.), Aquatic Applications of Ozone. International Ozone Institute, Cleveland, Ohio.

Oehschlaeger, H. F. 1978. Reactions of ozone with organic compounds. pp. 20-37. IN R. G. Rice and J. A. Cotruvo (eds.), Ozone/Chlorine Dioxide Oxidation Products of Organic Materials. International Ozone Institute, Cleveland, Ohio.

Pichet, P., and C. Hurtbise. 1976. Reactions of ozone in artificial sea water. pp. 664-670. IN R. G. Rice (ed.), Proc., Second International Symposium on Ozone Technology. International Ozone Institute, Cleveland, Ohio.

Pryde, E. H., D. J. More, and J. C. Cowan. 1968. Hydrolytic reductive and pyrolytic decomposition of selected ozonlysis products. Water as an ozonozation medium. J. Am. 0il Chem. Soc. 45:888-894.

Riebel, A. H., R. E. Erickson, C. J. Abshire, and P. S. Bailey. 1960. 0zonation of carbon-nitrogen double bonds. I. Nucleophilic at.t.ack of ozone. J. Am. Chem. Soc. 82:1801-1807. 
Rook, J. J. 1974. Formation of haloforms during chlorination of natural waters. Water Treat. Exam. 23:234-243.

Rosenlund, B. D. 1974. Disinfection of hatchery influent by ozonation and the effects of ozonated water on rainbow trout. pp. 59-67. IN W. J. Blogoslawski and R. G. Rice (eds.), Aquatic Applications of Ozone. International Ozone Institute, Cleveland, Ohio.

Sander, E., and H. Rosenthal. 19\%4. Application of oz̄one in water treatment. for home aquaria, public aquaria, and for aquaculture purposes. pp. 103-114. IN W. J. Blogoslawski and R. G. Rice (eds.), Aquatic Applications of 0zone. International Ozone Institute, Cleveland, Ohio.

Scott, D. B. M. 1975. The effect of ozone on nucleic acids and their derivatives. pp. 1-15. IN W. J. Blogoslawski and R. G. Rice (eds.), Aquatic Applications of 0zone. International Ozone Institute, Cleveland, Ohio.

Sengupta, C., G. Levine, E. C. Wackenhuth, and C. R. Geurra. 1974. Power plant cooling water treatment with ozone. pp. 120-137. IN W. J. Blogoslawski and R. G. Rice (eds.), Aquatic Applications of 0zone. International 0zone Institute, Cleveland, onhin.

Sennewald, K. 1933. Uber den Zerfall des Ozons in wasseriger Losung, 2. Phys. Chem. Abt. A164:305-317.

Shackleford, W. M., and L. H. Keith. 1976. Frequency of organic compounds identified in water. EPA-600/4-76-002. U.S. Environmental Protection Agency, Washington, D.C. 
Shapiro, R., K. J. Kolonko, P. M. Greenstein, R. M. Barkley, and R. E. Seivers. 1978. Ozonation products from caffeine in aqueous solution. pp. 284-290. IN R. G. Rice and J. A. Cotruvo (eds.), Ozone/Chlorine Dioxide Oxidation Products of Organic Materials. International Ozone Institute, Cleveland, Ohio.

Sievers, R. E., R. M. Barkley, G. A. Eiceman, R. H. Shapiro, H. F. Walton, K. J. Kolonko, and L. R. Field. 1977. Environmental trace analysis of organics in water by glass capillary column chromatography and ancillary techniques: Products of ozonolysis. J. Chromatogr. 142:745-754.

Sievers, R. E., R. M. Barkley, G. A. Eiceman, P. P. Haack, R. H. Shapiro, and H. F. Walton. 1978a. Generation of volatile organic compounds from nonvolatile precursors in water by treatment with chlorine or ozone. pp. 615-624. IN R. L. Jolley, H. Gorchev, and D. H. Hamilton; Jr. (eds.), Water Chlorination: Environmental Impact and Health Effects, Vol. 2. Ann Arbor Science Publishers, Ann Arbor, Michigan.

Sievers, R. E., R. H. Shapiro, H. F. Walton, G. A. Eiceman, and R. M. Barkley. 1978b. High resolution gas chromatographic determination of organic compounds in ozonized wastewater. IN S. P. 'Cram (ed.), High Resolution Gas Chromatography. Academic Press, New York.

Sobels, F. H. 1956. Organic peroxides and mutagenic cffects in Drosophila. Nature 4517:979-982. 
Spanggord, R. J., and V. J. McClurg. 1978. Ozone methods and ozone chemistry of selected organics in water. pp. 115-125. IN R. C. Rice and J. A. Cotruvo (eds.), Ozone/Chlorine Dioxide Oxidation Products of Organic Materials. International Ozone Institute, Clevel and, Ohio.

Straub, M. 1975. Water ozonation in fish culture. Schweiz. Z. Hydrol. $37(2): 289-293$.

Stumn, W. 1954. Der Zerfall von Ozon in Wasseriger Losung. Heiv. Chiiil. Acta $37: 773-778$.

Sturrock, M. G., E. L. Cline, and K. R. Robinson. 1963. The ozonation of phenanthrene with water as participating solvent. J. Org. Chem. 28:2340-2343.

Symons, J. M. 1976. Interim treatment guide for the control of chloroform and other trihalomethanes. Water Supply Research Division, Municipal Environmental Research Laboratory, U.S. Environmental Protection Agency, Cincinnati, Ohin,

Taube, $\mathrm{H}$. 1942. Reactions in solutions containing $\mathrm{O}_{3}, \mathrm{H}_{2} \mathrm{O}_{2}$, $\mathrm{H}^{+}$and $\mathrm{Br}^{-}$. The specific rate of the reaction $\mathrm{O}_{3}+\mathrm{Br}^{-}$. J. Am. Chem. Soc. 642:2468-2474.

Ioner, R. C., and B. Brooks. 1974. The effecls of ozone on four species of phytoplankton, crab zoe and megalops and the Atlantic Silverside, Menidia menidia. pp. 154-160. IN W. J. Blogoslawski and R. G. Rice (eds.), Aquatic Applications of Ozone. International Ozone Institute, Cleveland, Ohio. 
Toner, R. C., and B. Brooks. 1977. The effects of ozone on the larvae and juveniles of the mussel Mytilus edulis. pp. 19-22. IN L. D. Jensen (eds.), Biofouling Control Procedures. Marcel Dekker, New York.

Venosa, A. D. 1975. Ozone as a water and wastewater disinfectant: A literature review. pp. 83-100. IN F. L. Evans (ed.), Ozone in Water and Wastewater Treatment. Ann Arbor Science Publishers, Ann Arbor, Michigan.

Ward, R. W. 1976. Effects of residual ozone on aquatic organisms. pp. 260-265. IN E. G. Fochtman, R. G. Rice, and M. E. Browning (eds.), Disinfection with 0zone. International Ozone Institute, Cleveland, Ohio.

Ward, R. W., R. D. Griffin, G. M. DeGraeve, and R. A. Stone. 1976. Disinfection efficiency and residual toxicity of several wastewater disinfectants. EPA-600/2-76-156. Municipal Environmental Research Laboratory, U.S. Environmental Protection Agency, Cincinnati, Ohio.

Yocum, F. H. 1978. 0xidation of styrene with ozone in aqueous solution. pp. 243-263. IN R. G. Rice and J. A. Cotruvo (eds.), Ozone/Chlorine Dioxide Oxidation Products of Organic Materials. International Ozone Institute, Cleveland, Ohio. 


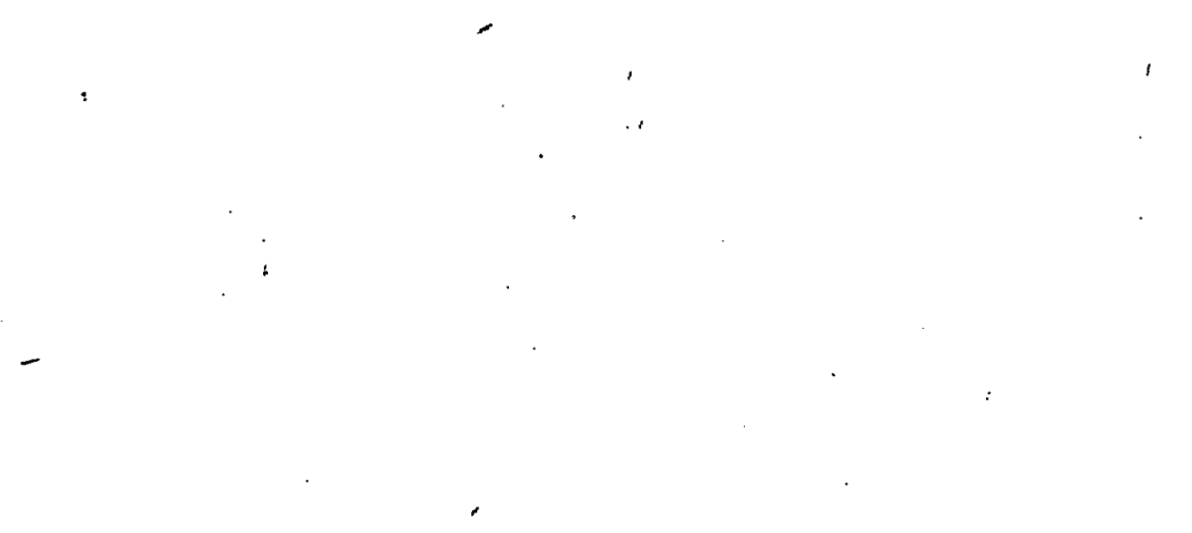

THIS PAGE

WAS INTENTIONALLY

LEFT BLANK 
ORNL/TM-6459

INTERNAL DISTRIBUTION

1- 5. S. M. Adams

6-15. S. I. Auerbach

16. B. G. Blay lock

17-21. R. W. Brocksen

22. R. Cooper

23. C. C. Coutant

24-28. R. A. Faust

29. D. E. Ferguson

30. J. R. Hightower

31-35. R. L. Jolley

36. R. L. Kroodsma

37. N. E. Lee

38. M. H. Lietzke

39-48. J. S. Mattice

49. R. B. McLean

50. W. W. Pitt

51. H. Postma
52. D. E. Reichle

53. C. R. Richmond

54. C. D. Scott

55. E. G. Struxness

56. J. E. . Thompson

57-61. J. R. Trabalka

62. D. B. Trauger

63. R. I. Van Hook

64. R. G. Wymer

65. H. E. Zittel

66. Biology Library

67-68. Central Research Library

69. ORNL Patent Office

70-71. Laboratory Records Depart.

72. Laboratory Records, ORNL-RC

73. ORNL Y-12 Technical Library

\section{EXTERNAL DISTRIBUTION}

74. Research and Technical Support Division, DOE-ORO.

75. H. C. Bailey, Stanford Research Institute, 333 Ravenwood Avenue, Men lo Park, CA 94025.

76. Charles Billups, Environmental. Specialists Branch, Directorate of Licensing, U.S. Nuclear Regulatory Commission, Washington, DC 20545

77. W. J. Blogos lawski, International Ozone Institute, Inc. 14805 Detroit Avenue, Cleveland, $\mathrm{OH} 44107$

78. W. A. Brungs, National Water Quality Laboratory, U.S. Environmental Protection Agency, Duluth, MN 55804

79. J. J. Davis, Research Coordination Office, Division of Safeguards, Fuel Cycle and Environmental Research, U.S.N.R.C., Washington, DC 20555

80. W. P. Davis, U.S. Environmental Protection Agency, Bears Bluff Field Station, P.0. Box 368, Johns Is land, SC 29455

81. Harold Denton, Division of Site Safety and Environmental Analysis, Office of Nuclear Reactor Regulation, Nuclear Regulatory Commission, Washington, DC 20555

8z. U. Uetwiller, tnvironmental Protection Agency, Environmental Research Laboratory, Athens, GA

83. P. Doudoroff, Department of Fisheries and Wildlife, Uregon State University, Corvallis, Oregon

84. J. A. Gerath, Jr., Maryl and Academy of Sciences, 601 Light St., Baltimore, MD 21230

85. N. E. Glass, Corall is Environmental Research Laboratory, USEPA, Corvallis, OR 
86. R. A. Goldstein, Electric Power Research Institute, P.0. Box 10412, Palo Alto, CA 94303

87. C. P. Goodyear, National Power Plant Team, U.S. Fish and WiTdlife Service, 1451 Green Road, Ann Arbor, MI 48107

88. L. B. Goss, Environmental Studies Section, Power Research Staff, 524 Power Building, Chattanooga, TN 37401

89. D. H. Hamilton, Jr., Division of Biomedical and Environmental Research, Department of Energy, Washington, DC 20545

90. C. R. Hickey, Nuclear Regulatory Commission, Washington, DC 20555

91. D. E. Hoss, National Marine Fisheries Service, NOAA, Beaufort, NC 28516

92. B. G. Isam, WQEB, E \& D Building, Muscle Shoals, AL 35660

93. Roger Jorden, Electric Power Research Institute, P.O. Box 10412, Palo Alto, CA 94303

94. R. Kawaratani, Electric Power Research Institute, P.0. Box 10412, Palo A7to, CA 94303

95. W. W. Kirby-Smith, Duke University, Marine Laboratory, Beaufort, NC 28516

96. G. H. Lauff, Director, Kellogg Biological Station, Michigan State University, Hiskory Corners, MI 49060

97. Library, Division of Environmental Planning, Tennessee Valley Authority, Chattanooga, Tennessee 37401

98. Library, Division of Forestry, Fisheries and Wildlife, Tennessee Valley Authority, Norris, Tennessee 37828

99. John W. Lum, 2806 Birdseye Lane, Bowie, MD 20715

100. J. J. Magnuson, Laboratory of Limnology, University of Wisconsin, Madison, WI 53706

101. D. Miller, Environmental Protection Agency, Environmental Research Laboratory, Narragansett, RI 02802

102. J. C. Morris, Division of Engineering and Applied Physics, Harvard University, Cambridge, MA 02138

103. W. Mott, Division of Control Technology, Department of Energy, Washington, DC 20545

104. D. I. Mount, National Water Quality Laboratory, U.S. Environmental Protection Agency, Duluth, MN 55804

105. W. J. Pasclak, Nuclear Regulatory Comnission, Washinyton, DC 20555

106. P. Reed, Office of Nuclear Regulatory Research, U.S.N.R.C., Washington, DC 20555

107. R. G. Rice, International 0zone Institute, Inc. 14805 Uetroit Avenue, Cleveland, $\mathrm{OH} 44107$

108. J. L. Swinebroad, Division of Biomedical and Environmental Research, Department of Energy, Germantown, MD 20767

109. R. S. Thorse11, Environmental Projects Manager, Edison Electric Institute, 90 Park Avenue, New York, NY 10016

110: Robert Watters, Division of Biomedicà and Environmental Research, Department of Energy, Washington, DC 20545

111. G. C. White, Consulting Engineer, San Francisco, CA 94118

112. J. H. Wilson, Jr., Office of Technology Impacts, Division of Environmental Impacts, Department of Energy, Washington, D.C. 10545

113-139. Technical Information Center, Oak Ridge, TN 37830 